\title{
Improvement in Linearity of Calibration Curves Using Matrix Components as Modifiers in ETV/ICP-MS and Application for SBT Thin Film
}

\author{
Hiroshi MITSUMATA and Toshio MORI \\ Lighting Company, Matsushita Electric Industrial Co., Ltd., 1-1, Saiwai-cho, Takatsuki-shi 569-1193
加熱気化/ICP-MSにおけるマトリックス成分補正方法の提案と SBT 薄膜中微量金属への適用

\author{
光亦博志·森 俊雄 \\ 松下電器産業(株)照明社, 569-1193 大阪府高梘市幸町 1-1
}

\begin{abstract}
We established a simple electrothermal vaporization (ETV)/inductively coupled plasma mass spectrometry (ICP-MS) technique without separating analyte elements from a matrix to determine trace metallic impurities of eight elements ( $\mathrm{Na}, \mathrm{Mg}, \mathrm{Al}, \mathrm{Cr}, \mathrm{Mn}, \mathrm{Fe}, \mathrm{Ni}$, and $\mathrm{Cu}$ ) in a Y-1 (strontium (Sr)-bismuth (Bi)-tantalum (Ta)oxygen $(O)$ ) thin film for semiconductor ferroelectric random-access memories. To improve the linearity of each calibration curve $\left(20 \mathrm{pg} \mathrm{ml}^{-1}-10 \mathrm{ng} \mathrm{ml}^{-1}\right)$, we added the same concentration of $\mathrm{Sr}$, Bi and Ta to a mixed standard solution as those in the sample solution as a mixed modifier. The recovery percentages obtained by adding $1 \mathrm{ng} \mathrm{ml}^{-1}$ of each element to the sample solution were between $\mathrm{Al}(90 \%)-\mathrm{Cr}(105 \%)$. The detection limit $(3 \sigma)$ was $1.9 \times 10^{10}(\mathrm{Mn})-1.3 \times 10^{12}(\mathrm{Al})$ atoms $\mathrm{cm}^{-2}$ for a $\mathrm{Y}-1$ thin film with a diameter of $150 \mathrm{~mm}$. The proposed method was applied to the real samples to determine the eight metallic elements $\left(10^{11}-10^{13}\right.$ atoms $\mathrm{cm}^{-2}$ ).

[Received January 29, 2006; Accepted June 15, 2006]
\end{abstract}

Key-words : Semiconductor ferroelectric random-access memories, $Y-1$, Thin film, Metallic impurities, ETV/ ICP-MS, Matrix modifier

\section{Introduction}

Determining metallic impurities in semiconductor materials is known to be very important, because of their influence on electric properties, $p-n$ junction leakage and the degradation of the oxide breakdown voltage et al. ${ }^{1,2)}$ For this determination, furnace atomic absorption spectrometry (FAAS), ${ }^{3)-5)}$ inductively coupled plasma mass spectrometry (ICP-MS $)^{6)-9)}$ and total-reflection X-ray fluorescence analysis (TRXF) ${ }^{10)-12)}$ are often been used. Despite these methods, a simple determination method for trace metallic impurities is required to develop new semiconductor materials, improve their properties and achieve high product yields for semiconductor devices. There have been a few reports on the analysis of ferroelectric materials ${ }^{1,13)}$ and its thin film ${ }^{2)}$ for semiconductor ferroelectric random-access memories and ferroelectric random-access memories have been receiving attention as a form of nonvolatile memory. ${ }^{14)}$ Yabuki reported on the analysis of metallic impurities in metal-oxide thin films using precipitation separation/nebulizer ICP-MS and FAAS. ${ }^{2)}$ Using these methods, it is possible to sensitively and accurately measure analyte elements. ${ }^{2}$ However, these methods are time consuming due to the process of separating analyte elements from the matrix. ${ }^{2)}$

As a ferroelectric material BST (referred to as $\mathrm{Y}-1$ hereafter) is composed of strontium $(\mathrm{Sr})$, bismuth $(\mathrm{Bi})$, tantalum $(\mathrm{Ta})$ and oxygen $(\mathrm{O}),{ }^{15)}$ trace metallic impurities exist with the matrices $\mathrm{Sr}, \mathrm{Bi}$, and $\mathrm{Ta}$ in the $\mathrm{Y}-1$ sample solution. ${ }^{1)}$ In the nebulizer type ICP-MS, $\mathrm{Fe}$ is one of the elements that is influenced by molecular ions such as ${ }^{40} \mathrm{Ar}^{16} \mathrm{O}$ due to argon, solvents et al. Using cool plasma in this method, the $\mathrm{Fe}$ ion intensity is depressed by the matrix. Avoiding this type of depression by diluting the elements results in a reduction in the sensitivity of the real measurements. On the other hand, electrothermal vaporization (ETV)/ICP-MS is available for mul- tielemental measurements of the micro sample solution ${ }^{6)-8)}$ and it also avoids the spectral influences of ${ }^{40} \mathrm{Ar}^{16} \mathrm{O}$ on the ${ }^{56} \mathrm{Fe}$ ion intensity that occurs in the nebulizer type ICP-MS. In particular, for the high matrix concentration of the sample solution, using the nebulizer type ICP-MS for a long time measurement, an introduction system such as the skimmer cone is probably plugged due to the matrix components, while the problems associated with the introduction system do not occur in ETV/ICP-MS because the amount of the sample introduction to ICP in the ETV type is a one-dozenth less than that in the nebulizer type.

In the meantime, with ETV/ICP-MS, using a "matrix modifier" is beneficial. The matrix modifier can be classified as a physical modifier or a chemical modifier according to the manner in which it functions. As for the former case, it functions as a carrier for preventing the analyte vaporized in the ETV chamber from condensing in the sample-introduction system leading to the ICP. Improved analysis sensitivity and linearity of the calibration curve due to this function, have been reported. ${ }^{16)-20)}$ On the other hand, as for the latter case, it has been reported that lowering the vaporization temperature of the matrix but raising the vaporization temperature of the analyte improves the inspection and analysis sensitivity of the separation technique. ${ }^{19)-23)}$ In establishing the analysis method, although previous reports have become the standard for selecting the modifier, fundamentally, it is necessary to select the suitable modifier for the matrix and the analyte on a case-by-case experimental basis.

The purpose of this work is to establish a simple ETV/ ICP-MS without separating analyte elements from a matrix before measurements. We examined a matrix modifier for determining a $\mathrm{Fe}$ impurity in the $\mathrm{Y}-1$ thin film, and obtained a calibration curve with good linearity for $\mathrm{Fe}$ by adding the same concentration of $\mathrm{Sr}, \mathrm{Bi}$ and $\mathrm{Ta}$ to a mixed standard solu- 
Table 1. ETV Operating Conditions

\begin{tabular}{lccc}
\hline Stage & Temperature $/{ }^{\circ} \mathrm{C}$ & Ramp $/ \mathrm{s}$ & Hold $/ \mathrm{s}$ \\
\hline Drying & 90 & 10 & 0 \\
& 120 & 15 & 30 \\
& 100 & 0 & 20 \\
Vaporization & 2400 & 0 & 5 \\
Cleanup & 2800 & 0 & 3 \\
\hline Carrier Ar flow rate $0.91 \mathrm{ml}^{-1}$, Sample injection volume $25 \mu 1$. &
\end{tabular}

tion as those in the sample solution. Furthermore, we obtained calibration curves with good linearity for the other seven elements $(\mathrm{Na}, \mathrm{Mg}, \mathrm{Al}, \mathrm{Cr}, \mathrm{Mn}, \mathrm{Ni}$, and $\mathrm{Cu})$ in the same manner. The proposed method was applied to determine the eight metallic elements $\left(10^{11}-10^{13}\right.$ atoms $\left.\mathrm{cm}^{-2}\right)$ in the ferroelectric film samples on a silicon $(\mathrm{Si})$ wafer with a diameter of 150 $\mathrm{mm}$.

\subsection{Reagent and sample}

\section{Experimental}

We used the same reagents and water as in the previous work $^{24)}$ except for the $\mathrm{Sr}, \mathrm{Bi}$ and Ta standard solutions (1000 $\mu \mathrm{g} \mathrm{ml}^{-1}$ of each element) from SPEX (CertiPrep Inc., Metuchen, N. J., USA). We deposited Y-1 thin film samples: $\mathrm{SrBi}_{2.1} \mathrm{Ta}_{1.9} \mathrm{O}_{\mathrm{x}}$ (ca. $200 \mathrm{~nm}$ thickness) $/ \mathrm{Pt} / \mathrm{SiO}_{2} / \mathrm{Si}$-substrate (diameter of $150 \mathrm{~mm})$ ) on a $\mathrm{Si}$ wafer by a metal-organic decomposition (MOD) method using alchoxide.

\subsection{Apparatus}

We employed an ICP mass spectrometer, a furnace for the ETV and a autosampler in the previous work, ${ }^{24)}$ and employed an ICPS-8000, an inductively coupled plasma-atomic emission spectrometry (ICP-AES) system (Shimadzu, Kyoto) for determining $\mathrm{Sr}, \mathrm{Bi}$, and $\mathrm{Ta}$ in the thin film samples.

\subsection{Procedure}

We set a Y-1 thin film sample on Si wafer was set in the decomposition vessel. Five milliliters of a mixed acid (HF : $\left.\mathrm{HNO}_{3}=1: 1\right)$ were added to the film sample, and we decomposed the sample using an illuminating IR lamp. We then diluted the recovered solution to $500 \mathrm{ml}$ with water. The $25 \mu \mathrm{l}$ of the sample solution was injected into the graphite boat, after which we measured the ion intensities from group 1 ${ }^{(23} \mathrm{Na},{ }^{24} \mathrm{Mg},{ }^{27} \mathrm{Al},{ }^{53} \mathrm{Cr}$ and $\left.{ }^{55} \mathrm{Mn}\right)$ to group $2\left({ }^{56} \mathrm{Fe},{ }^{60} \mathrm{Ni},{ }^{63} \mathrm{Cu}\right)$ using the operating conditions for ICP-MS in the previous work $^{24)}$ and using the operating conditions for ETV shown in Table 1. In order to cancel the decrease of the analyte element ion intensities due to transport loss using only mixed standard solutions, we matched the mixed standard solutions for the calibration curve to the matrices of the sample solution.

The treatment for preparing the sample solution and the standard solution was carried out on a class-100 clean bench. The ETV/ICP-MS measurements were carried out in a class1000 clean room.

\section{Results and discussion}

3.1 Effect of the concentration of $\mathrm{Sr}, \mathrm{Bi}, \mathrm{Ta}$ and $\mathrm{Pd}$ on $\mathrm{Fe}$ ion intensities

To select a matrix modifier, we examined the effects of the concentration of the $\mathrm{Y}-1$ matrix components $\mathrm{Sr}, \mathrm{Bi}, \mathrm{Ta}$, and a $\mathrm{Pd}$ matrix modifier used in the previous work ${ }^{24)}$ on $\mathrm{Fe}$ ion intensities at the concentration of $\mathrm{Fe} 1 \mathrm{ng} \mathrm{ml}^{-1}$. The results are shown in Fig. 1. The behavior of $\mathrm{Fe}$ ion intensity can be

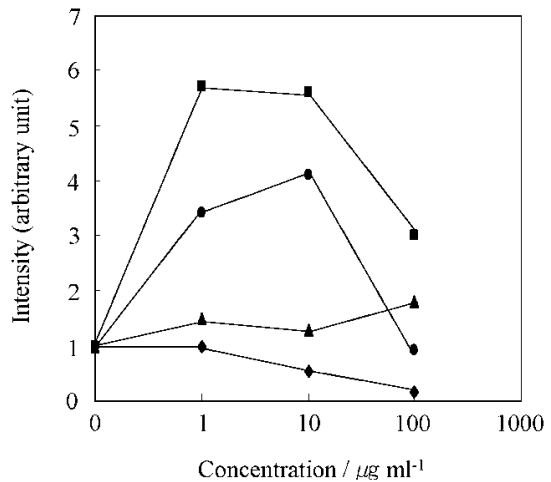

Fig. 1. Effect of the concentration of strontium, bismuth, tantalum and palladium on iron ion intensity. $\mathrm{Fe} 1 \mathrm{ng} \mathrm{ml}^{-1}$, Strontium, Palladium, $\Delta$ Tantalum, Bismuth.

explained in terms of the transport efficiency of $\mathrm{Fe}$ ions and the atomic-weight effect ${ }^{25)}$ of coexisting elements. In the case of coexistence of $\mathrm{Sr}$ and $\mathrm{Pd}$ at concentrations up to $10 \mu \mathrm{g}$ $\mathrm{ml}^{-1}, \mathrm{Fe}$ ion intensity increases as a result of improved transport efficiency accompanying the physical modifier effect of these two elements. However, it is considered that the decrease in $\mathrm{Fe}$ ion intensity due to the atomic-weight effects of $\mathrm{Sr}$ and $\mathrm{Pd}$ is even stronger. Moreover, in the case of coexistence of $\mathrm{Sr}$ at a high concentration, namely, $100 \mu \mathrm{g} \mathrm{ml}^{-1}$, the decrease effect on $\mathrm{Fe}$ ion intensity due to the atomic-weight effect of $\mathrm{Sr}$ decreases the $\mathrm{Fe}$ ion intensity that had been increasing up to that concentration. In the case of coexistence of $\mathrm{Pd}$ at a concentration of $100 \mu \mathrm{g} \mathrm{ml}^{-1}$, the decrease in Fe ion intensity due to the atomic-weight effect of Pd is large, and the Pd-addition effect is not shown. Moreover, it is confirmed in Fig. 1 that as the mass number of the coexisting element increases, the decrease in $\mathrm{Fe}$ ion intensity gets bigger in approximate accordance with the atomic-weight effect. The reason for the slight increase in $\mathrm{Fe}$ ion intensity under coexistence of $\mathrm{Ta}$ at concentration of $100 \mu \mathrm{g} \mathrm{ml}^{-1}$ in comparison with the $\mathrm{Fe}$ ion intensity at Ta concentrations up to $10 \mu \mathrm{g} \mathrm{ml}^{-1}$ is unknown. Furthermore, as for the atomic-weight effect, ${ }^{25)}$ in the sample-introduction system between the ICP and the mass spectrometer, the analyte ions collide with coexisting elements with higher mass number, and go astray from their primary trajectory, thereby decreasing the introduction efficiency of the analyte ions into the mass spectrometer (i.e., ion intensity decrease). The influence of coexisting elements with high mass number on the ion intensity is therefore big.

From these results, we did not use $\mathrm{Sr}, \mathrm{Bi}, \mathrm{Ta}$, and $\mathrm{Pd}$ as a modifier, because the positive effects of adding the Pd modifier as shown in the previous work ${ }^{24)}$ were not observed this time.

\subsection{Effect of the concentration of synthetic $Y-1$ compo- nents on $\mathrm{Fe}$ ion intensities}

We prepared mixed standard solutions containing $\mathrm{Sr}, \mathrm{Bi}$, and $\mathrm{Ta}$ in concentration $\left(\mu \mathrm{g} \mathrm{ml}^{-1}\right)$ ratio ( $\mathrm{Sr} \mathrm{1:} \mathrm{Bi} \mathrm{5:} \mathrm{Ta} \mathrm{4)}$ adjusted to Y-1 composition, and examined the effect of the mixed standard solution on $\mathrm{Fe}$ ion intensities at the concentration of $\mathrm{Fe} 1 \mathrm{ng} \mathrm{ml}^{-1}$. The results are shown in Fig. 2. We observed a larger increase of $\mathrm{Fe}$ ion intensity at a concentration range (Sr: $0.1-1 \mu \mathrm{g} \mathrm{ml}^{-1}$, Bi: $0.5-5 \mu \mathrm{g} \mathrm{ml}^{-1}$, Ta: $0.4-4 \mu \mathrm{g}$ $\mathrm{ml}^{-1}$ ). Thus, we used Sr $1 \mu \mathrm{g} \mathrm{ml}^{-1}$, Bi $5 \mu \mathrm{g} \mathrm{ml}^{-1}$ and Ta $4 \mu \mathrm{g}$ $\mathrm{ml}^{-1}$ as a mixed modifier in this work.

3.3 Calibration curve, recovery, and detection limit

The correlation coefficient, recovery percentage, and detec- 


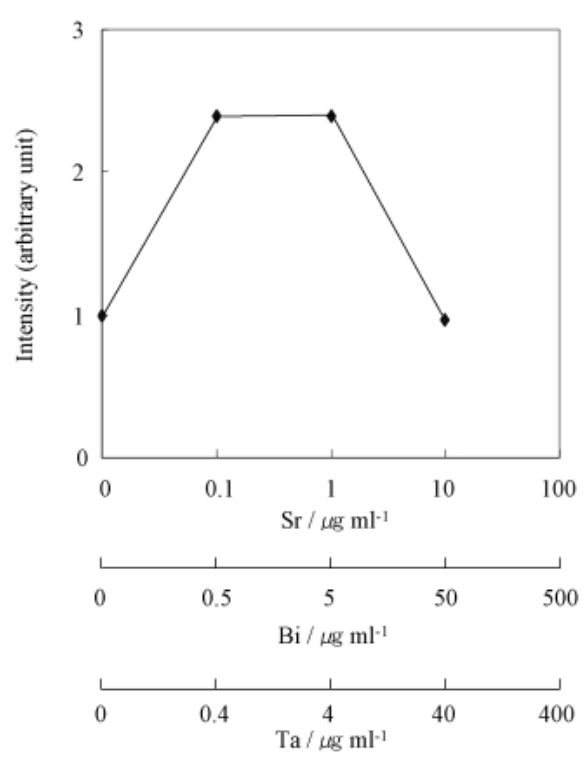

Fig. 2. Effect of the concentration of synthetic $\mathrm{Y}-1$ components on iron ion intensity. $\mathrm{Fe} 1 \mathrm{ng} \mathrm{ml}^{-1}$.

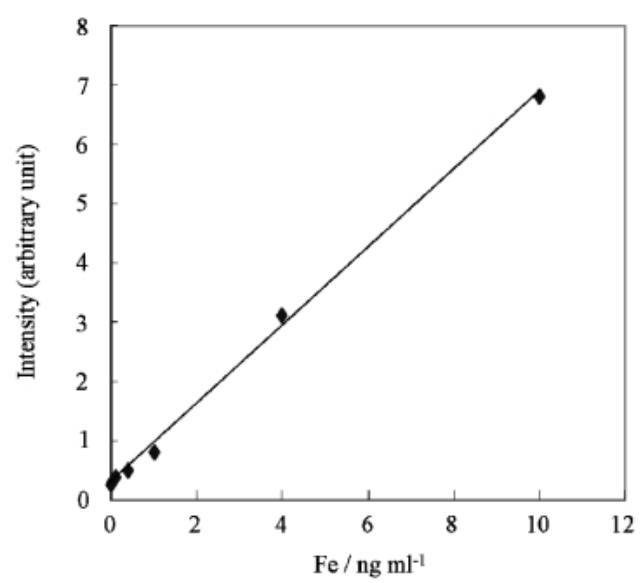

Fig. 3. Calibration curve for iron.

tion limit were examined using mixed standard solutions ranging from $20 \mathrm{pg} \mathrm{ml}^{-1}$ to $10 \mathrm{ng} \mathrm{ml}^{-1}$ that contained $\mathrm{Sr}(1 \mu \mathrm{g}$ $\left.\mathrm{ml}^{-1}\right), \mathrm{Bi}\left(5 \mu \mathrm{g} \mathrm{ml}^{-1}\right)$, and $\mathrm{Ta}\left(4 \mu \mathrm{g} \mathrm{ml}^{-1}\right)$ as the mixed modifier. As shown in Fig. 3, the calibration curve obtained for $\mathrm{Fe}$ was linear and had a high correlation coefficient of 0.999 . The calibration curves for the other seven elements obtained in the same manner as that for $\mathrm{Fe}$ were also linear, with high correlation coefficients of $0.998(\mathrm{Cr})$ and 0.999 (each of other six elements), although these results are not shown here. Incidentally, as described in the previous work, ${ }^{24)}$ using only mixed standard solutions without adding a modifier, significant ion intensity losses were observed in the eight calibration curves obtained. To certify the accuracy of this method, we examined the recovery percentage of the eight elements. One nanogram per milliliter of eight elements was added to the real sample solution. Good recovery percentages of $93 \%(\mathrm{Na}), 91 \%(\mathrm{Mg}), 90 \%(\mathrm{Al}), 105 \%(\mathrm{Cr}), 97 \%$ $(\mathrm{Mn}), 100 \%(\mathrm{Fe}), 94 \%(\mathrm{Ni})$, and 104\% $(\mathrm{Cu})$ were obtained. The detection limits $(3 \sigma)$ are shown in Table 2 . The detection limits were between $\mathrm{Mn}\left(0.6 \mathrm{pg} \mathrm{ml}^{-1}, 1.9 \times 10^{10}\right.$ atoms $\left.\mathrm{cm}^{-2}\right)$ $\mathrm{Al}\left(20 \mathrm{pg} \mathrm{ml}^{-1}, 1.3 \times 10^{12}\right.$ atoms $\left.\mathrm{cm}^{-2}\right)$. Most of the detection
Table 2. Detection Limits $\left(\times 10^{11}\right.$ atoms $\left.\mathrm{cm}^{-2}\right)$

\begin{tabular}{ccc}
\hline $\begin{array}{c}\text { Analyte } \\
\text { Element }\end{array}$ & $\mathrm{pg} \mathrm{ml}^{-1}$ & ETV/ICP-MS \\
\hline $\mathrm{Na}$ & 3 & 2.2 \\
$\mathrm{Mg}$ & 2 & 1.4 \\
$\mathrm{Al}$ & 20 & 13 \\
$\mathrm{Cr}$ & 20 & 6.6 \\
$\mathrm{Mn}$ & 0.6 & 0.19 \\
$\mathrm{Fe}$ & 10 & 3.1 \\
$\mathrm{Ni}$ & 6 & 1.7 \\
$\mathrm{Cu}$ & 5 & 1.3 \\
\hline
\end{tabular}

*Thin film sample with diameter of $150 \mathrm{~mm}$

Table 3. Analytical Results of Trace Impurities in Ferroelectric Y-1 Film Samples $\left(\times 10^{12}\right.$ atoms $\left.\mathrm{cm}^{-2}\right)$

\begin{tabular}{ccc}
\hline $\begin{array}{r}\text { Analyte } \\
\text { element }\end{array}$ & Sample A* $^{*}$ & Sample B* $^{*}$ \\
\hline $\mathrm{Na}$ & 3.9 & 7.4 \\
$\mathrm{Mg}$ & 1.5 & 3.9 \\
$\mathrm{Al}$ & 7.4 & 13 \\
$\mathrm{Cr}$ & 2.7 & 2.2 \\
$\mathrm{Mn}$ & 0.21 & 0.48 \\
$\mathrm{Fe}$ & 1.1 & 6.3 \\
$\mathrm{Ni}$ & 0.78 & 0.73 \\
$\mathrm{Cu}$ & 0.48 & 1.0 \\
\hline
\end{tabular}

*Thin film sample with diameter of $150 \mathrm{~mm}$, Sample A: developed prototype, Sample B: a manufactureís product

limits were less than those calculated from minimum limits of determination $\left(\mathrm{Ni}: 1 \times 10^{10}\right.$ atoms $\mathrm{cm}^{-2}$, Mn: $2 \times 10^{10}$ atoms $\mathrm{cm}^{-2}$ et al.) of Yabuki. ${ }^{2)}$

\subsection{Application}

The analytical results of real ferroelectric film samples (sample A: developed prototype; B: a manufacturer's product) with a diameter of $150 \mathrm{~mm}$ are shown in Table 3. The values for $\mathrm{Al}$ were approximately $10^{13}$ atoms $\mathrm{cm}^{-2}$ in samples $\mathrm{A}$ and $\mathrm{B}$, while the values for Mn were approximately $10^{11}$ atoms $\mathrm{cm}^{-2}$. The $\mathrm{Na}$ and $\mathrm{Fe}$ values were approximately $10^{13}$ atoms $\mathrm{cm}^{-2}$ in sample B. Except for these results, the values of $\mathrm{Na}, \mathrm{Mg}, \mathrm{Cr}, \mathrm{Fe}, \mathrm{Ni}$ and $\mathrm{Cu}$ were approximately $10^{12}$ atoms $\mathrm{cm}^{-2}$. It is considered that the difference in impurity concentrations of samples A and B is due to differences in the purity of the film raw materials and film-formation conditions. From the above results, an improvement in the impurity level occurred, resulting in a Y-1 thin film of good quality. And in the case of samples 1 to 5 , the time needed for this analysis method is about half that needed for Yakubi's method. ${ }^{2)}$ The proposed method would be especially useful for analyzing a lot of samples having the same composition because the determination for the composition of one sample is only required.

Acknowledgements We wish to thank Prof. Yasumasa Shigetomi of Okayama University of Science for his helpful advice in this work.

\section{References}

1) Fujiwara, K., Mori, T., Atagi, T., Atagi, T., Mitsumata, H. and Nakahara, T., Bunseki Kagaku, Vol. 48, pp. 103-110 
(1999).

2) Yabuki, M., Bunseki Kagaku, Vol. 52, pp. 447-453 (2003).

3) Nagasawa, H. and Enomoto, M., Bunseki Kagaku, Vol. 46, pp. 375-379 (1997)

4) Sako, N., Tanaka, H., Toyoda, M., Naka, J. and Kuramoto, K., Bunseki Kagaku, Vol. 43, pp. 771-776 (1994).

5) Nagasawa, H., Kato, Y. and Enomoto, M., Bunseki Kagaku, Vol. 44, pp. 953-956 (1995).

6) Chung, H. Y., Kim, Y. H., Cho, H. Y., Lee, B. Y., Yoo, H. D. and Lee, S. H., Anal. Sci., Vol. 17, pp. 653-658 (2001).

7) Yamada, Y., Tachibe, T., Shimazaki, A., Takenaka, M. and Kozuka, S., Bunseki Kagaku, Vol. 50, pp. 453-458 (2001).

8) Fujiwara, K., Toumori, Y., Mitsumata, H., Inada, M. and Nakahara, T., Bunseki Kagaku, Vol. 48, pp. 681-685 (1999).

9) Ruth, K., Schmidt, P. and Mori, E. J., Spectroscopy, Vol. 7, pp. 36-39 (1992)

10) Yamagami, M., Nonoguchi, M., Yamada, T., Shoji, T., Utaka, T., Mori, Y., Nomura, S., Taniguchi, K., Wakita, H. and Ikeda, S., Bunseki Kagaku, Vol. 48, pp. 1005-1011 (1999).

11) Hunabashi, M., Utaka, T. and Arai, T., Spectrochim. Acta, Part B, Vol. 52, pp. 887-899 (1997).

12) Pahlke, S., Fabry, L., Kotz, L., Mantler, C. and Ehmann, T. Spectrochim. Acta, Part B, Vol. 56, pp. 2261-2274 (2001).

13) Fukuda, M., Shimura, K. and Takeya, M., Bunseki Kagaku, Vol. 48, pp. 835-840 (1999).
14) Uemoto, Y., Jpn. J. Appl. Phys., Vol. 67, pp. 1256-1262 (1998).

15) U.S.P. 5,803,961.

16) Ediger, R. D. and Beres, S. A., Spectrochim, Acta, Part B, Vol. 47, pp. 907-922 (1992).

17) Kantor, T. and Margaretha, T. C., Spectrochim. Acta, Part B, Vol. 60, pp. 333-343 (2005).

18) Gregoire, D. C. and Sturgeon, R. E., Spectrochim. Acta, Part $B$, Vol. 54, pp. 773-786 (1999).

19) Uggerud, H. T. and Lund W., Spectrochim. Acta, Vol. 54, pp. 1625-1636 (1999).

20) Gregoire, D. C., Al-Maawali, S. and Chakrabarti, C. L., Spectrochim. Acta, Part B, Vol. 47, pp. 1123-1132 (1992).

21) Hughes, D. M., Gregoire, D. C., Naka, H. and Chakrabarti, C. L., Spectrochim. Acta, Part B, Vol. 52, pp. 517-529 (1997).

22) Wanner, B., Richner, P. and Magyar, B., Spectrochim. Acta, Part B, Vol. 51, pp. 817-827 (1996).

23) Yan-Zhong, L. and Zhe-Ming, N., Spectrochim. Acta, Part B, Vol. 49, pp. 229-241 (1994).

24) Mitsumata, H. and Mori, T., J. Ceram. Soc. Japan, Vol. 114 pp. 210-213 (2006).

25) Kawaguchi, H., "Purazuma Iongen Sitsuryobunseki," Ed. by Kawaguchi, H. and Nakahara, T., Gakkai Shuppansenta (1994) pp. 56-58 [in Japanese]. 